\title{
Karen Vallgårda
}

Karen Vallgårda, cand.mag. og ph.d. er adjunkt i historie på SAXO-Instituttet, Københavns Universitet. I sin ph.d.afhandling såvel som i sit nuværende forskningsprojekt om skilsmisser i Danmark 1885-2015 undersøger hun følelseshistoriske problemstillinger. Hun har publiceret en række artikler i danske og internationale tidsskrifter om temaer som kolonialisme, mission, køn og omvendelse. Hun er medredaktør på antologien Faith Through Feeling. Emotions and Christian Missions, 1600-1930, som er under udgivelse.

\section{FØLELSESHISTORIE - TEORETISKE BRUDFLADER OG UDFORDRINGER}

Følelseshistorie er et forskningsfelt i eksplosiv vækst. Med udgangspunkt i væsentlige nyere bidrag inden for historiefaget og kulturstudier diskuterer artiklen de centrale teoretiske problemstillinger, forskere konfronteres med, når de vil undersøge følelser i forskellige historiske kontekster: Hvordan skal vi definere følelser? I hvor høj grad er de socialt konstituerede og kulturelt specifikke? Er der noget naturgivent og universelt ved det menneskelige følelsesliv? Artiklen taler for at undersøge følelser som en form for praksis, der udspringer fra en social struktureret krop, og som påvirker de sociale sammenhænge, hvori de udøves. ${ }^{1}$

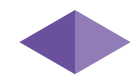

Siden midt-80'erne er følelseshistorie vokset frem som et særskilt forskningsfelt, og inden for det seneste årti har feltet været i eksplosiv vækst. ${ }^{2}$ Centre og netværk for følelseshistorie er etableret på forskningsinstitutioner og universiteter i blandt

1 Tak til Anne Katrine Kleberg Hansen, Birgitte Schepelern Johansen, Caroline Nyvang, Niklas Olsen, Signild Vallgårda og to anonyme fagfællebedømmere for gode kommentarer og ændringsforslag.

2 At historikere forholder sig til de fortidige aktørers følelser er imidlertid ikke nyt. Som Peter Gay har påpeget, benytter mange historikere sig endda ofte ubevidst af psykologiske teorier $i$ analyser af historiske aktørers følelsesliv og handlinger: "The professional historian has always been a psychologist, an amateur psychologist." Gay, 1986:6. Se også Bourke, 2003:115. 
andet Australien, Storbritannien, Sverige, Tyskland og USA, ${ }^{3}$ og på internationalt plan udgives utallige artikler og bøger, der tematiserer følelser i forskellige historiske kontekster. ${ }^{4}$ Også i Danmark er der stigende interesse for området. I foråret 2012 afholdt SAXO-Instituttet på Københavns Universitet en konference for følelseshistorie, og flere nye afhandlinger behandler følelseshistoriske problemstillinger. ${ }^{5}$

Snarere end en ny teoretisk skole er det følelseshistoriske felt karakteriseret ved mange forskellige tilgange og empiriske foci. Nogle forskere bruger følelser som et prisme til at undersøge nye aspekter af konkrete begivenheder - alt fra britiske soldaters oplevelse på slagmarken i Første Verdenskrig til fremvæksten af antisemitisme i det tidligt moderne Spanien - eller af mere almene og universelle fænomener såsom religiøs omvendelse, skilsmisse eller død. Andre studerer udviklingen i teorier om følelser og historiske forandringer i følelsesbegrebsapparatet eller sporer en enkelt følelse over tid. Endnu andre undersøger, hvordan følelser som kærlighed, solidaritet, medlidenhed, skam, og væmmelse har været med til at forme og omforme sociale mønstre ved at etablere fællesskaber og trække grænser.

Da forskningen nu er så omfangsrig, at den i sin helhed umuligt ville kunne behandles tilfredsstillende her, vil jeg ikke forsøge at give et komplet overblik. ${ }^{6}$ I stedet vil jeg med udgangspunkt i nogle af de væsentligste nyere bidrag inden for historiefaget og kulturstudier reflektere over de centrale teoretiske problemstillinger, forskere konfronteres med, når vi vil undersøge følelser historisk: Hvordan skal vi definere følelser? I hvor høj grad er de socialt konstituerede og kulturelt specifikke? Er der noget naturgivent og universelt ved det menneskelige følelsesliv? Og ikke mindst, hvordan kan vi forstå eller forklare følelsesmæssige ændringer over tid? Som disse spørgsmål antyder, ligner følelseshistoriens tematikker på mange måder dem, der har præget den kulturelle vending inden for historiefaget og beslægtede discipliner de sidste 30-40 år. Her har jeg valgt især at fokusere på spørgsmål, der knytter sig til nyere forskningsdiskussioner om følelsers historici-

3 De mest toneangivende er pt. History of Emotions på Max Planck Institut für Bildungsforschung i Berlin, Center for the History of the Emotions, Queen Mary University, London og ARC Center of Excellence for the History of the Emotions i Australien.

4 For nyere oversigtsværker, se Frevert, 2011; Hitzer, 2011 og Stearns, 2008 samt Plamper, 2012, som også er under udgivelse på engelsk på Oxford University Press. For en mere metodisk introduktion, se Rosenwein, 2010.

5 Vallgårda, 2012; Schjerning, 2013. Peter Wessels nyligt forsvarede afhandling "Den skjulte fattigdom. Middelstandens fattige i København 1750-1850” på KU har også en stærk følelseshistorisk vægtning. Se desuden Wessel, 2012. Hugo Nordland på Lunds Universitet arbejder ligeledes på en følelseshistorisk afhandling og har udgivet en kort introduktion til følelseshistorie: Nordland, 2012. Inden for litteratur- og kulturstudier i Danmark er der endvidere en stigende interesse for affekt. I 2012 udkom eksempelvis en udgave af Varia (9) med titlen "I affekt. Skam, frygt og jubel som analysestrategi" Se Frederiksen, 2012.

6 For henvisning til sådanne oversigter, se fodnote 4. 
tet. Hverken forholdet mellem følelser og rumlighed eller det mellem følelser og materialitet behandles derfor her, selvom begge åbner for interessante perspektiver, også i forbindelse med historiske studier. ${ }^{7}$ På samme baggrund udelader jeg en diskussion af den senere tids udvikling inden for psykologi og neurovidenskab. $^{8}$

I artiklen vil jeg argumentere for, at udfordringen for følelseshistorikere i dag netop er at definere et operationalisérbart følelsesbegreb, som dels fanger følelsernes sociale konstituering, dels indebærer et forklarende princip for følelsesmæssige forandringer over tid. Selvom ingen teoretikere endnu helt har klaret den udfordring, er den tyske historiker Monique Scheers Bourdieu-inspirerede begreb følelsespraksisser (emotional practices) en god indgang. Begrebet gør det muligt at flytte fokus fra den vanskelige - og måske i sidste ende uløselige - problematik om følelsernes ontologiske status til en undersøgelse af, hvordan følelser gøres.

Følelsespraksisbegrebet bliver særligt nyttigt, hvis det kombineres med teorier om, hvordan følelser ikke bare afspejler, men også påvirker sociale relationer og magtforhold. Med udgangspunkt i nyere bidrag til den postkoloniale følelsesforskning kan man hævde, at det er følelsernes sociopolitiske effekter, der gør dem særligt vigtige og interessante at undersøge i et historisk perspektiv. I artiklens sidste afsnit viser jeg, hvordan følelsespraksisbegrebet på produktiv vis kan tænkes sammen med sådanne postkoloniale analyser af følelsernes magtmæssige betydninger.

Inden for historiedisciplinen bruges "følelse", (känsla, Gefühl, feeling, emotion, etc.) almindeligvis som samlebegreb for feltet, mens "affekt" er det mest anvendte begreb inden for kultur- og mediestudier. Nogle teoretikere hævder, som det vil fremgå nedenfor, at der er afgørende forskel på "affekt” og "følelse”, men andre bruger de to begreber synonymt. Her diskuterer jeg derfor begge begreber både samlet og adskilt.

\section{Dikotomier etableres i følelseshistoriografien}

Dikotomier som følelse/intellekt, natur/kultur, samfund/individ, indre/ydre, oplevelse/udtryk og universelt/specifikt præger megen nyere følelseshistorie. Mens nogle forskere forsøger at nedbryde sådanne modsætningspar, taler andre for de-

7 I sin afhandling om følelser i de sene 1700-tals København behandler Camilla Schjerning blandt andet spørgsmålet om forholdet mellem rumlighed og følelser, særligt med henblik på de forskellige normer, der gør sig gældende i hhv. byens forskellige geografiske steder, såsom det, hun karakteriserer som den private og det offentlige rum. Schjerning, 2013. For en analyse af "følelseshåndtering" i nutidige lægepraksisser, der blandt andet behandler betydningen af sociomaterielle praksisser, se Jespersen, 2008:91-116.

8 I Frevert, 2011:19-27 berører den tyske historiker Ute Frevert forskelligheden i de historiske/ kulturteoretiske og det psykologiske/neurobiologiske begrebsapparater og erkendeinteresser. 


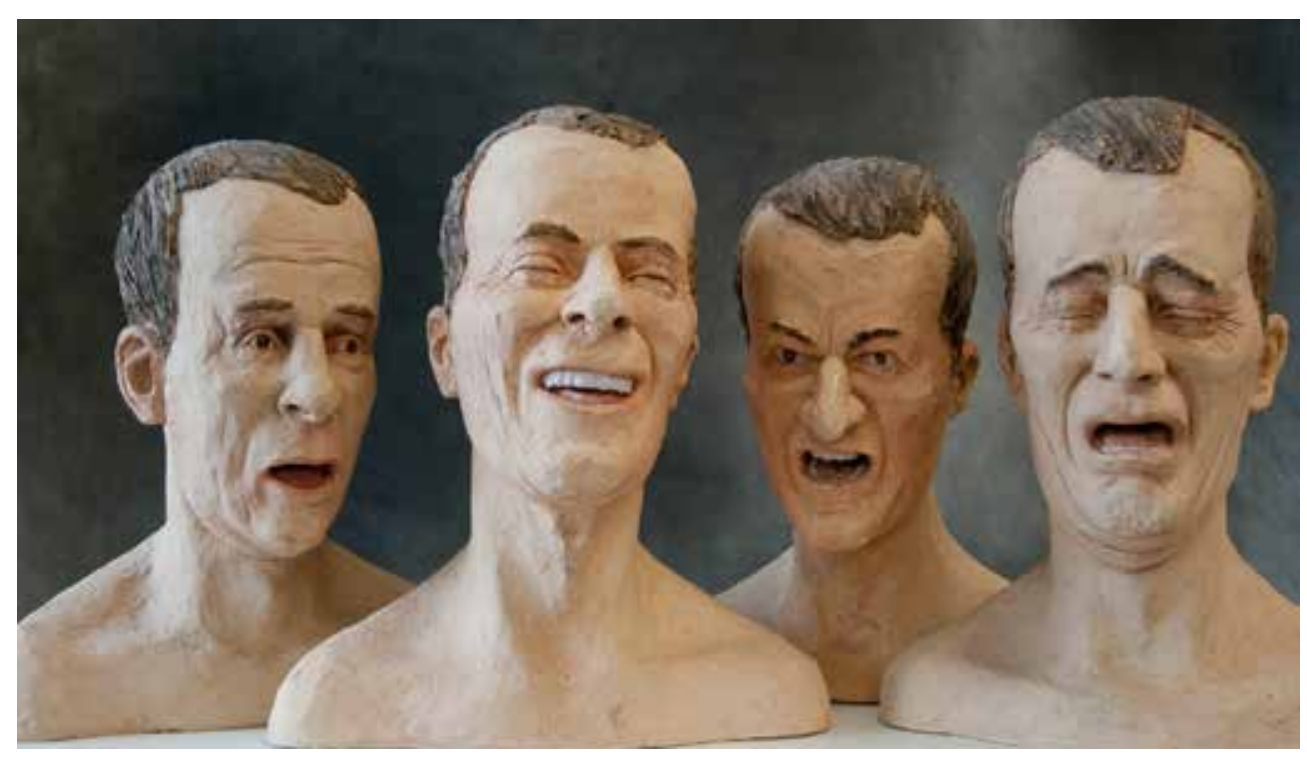

Portrait of a Man 2004-2006 (keramik og pigment) af Gert Germeraad. Foto: Gert Germeraad.

res (delvise) relevans i studiet af følelser. Disse dikotomier blev indskrevet i det følelseshistoriske begrebsapparat med den franske Lucien Febvres manifest La Sensibilité et l'Histoire fra 1941.

For Febvre stod følelser i kontrast til intellektet. De var smitsomme størrelser, som opstod i individets "indre organiske dyb" (fond organique), men som derfra kunne overføres til andre mennesker. ${ }^{9}$ Inspireret af den samtidige franske psykolog Henri Wallon argumenterede Febvre for, at det var følelser, der i tidernes morgen havde bragt mennesker sammen i samfund. Samfundet var på den anden side forudsætningen for den historiske udvikling af intellektet. Selvom det menneskelige intellekts evolution dermed havde sin rod i følelseslivet, opstod der ifølge Febvre snart en direkte modsætning mellem følelser og intellekt. Med intellektets hjælp lærte mennesker i nogen grad at undertrykke og styre følelser, ${ }^{10}$ men følelserne eksisterede som latente kræfter i mennesket med potentiale for at bryde ud og smitte andre. Nazismens fremmarch i Europa, som Febvre var vidne til, burde ifølge historikeren tjene til advarsel om, at

”Der inden i enhver af os er et følelsesliv, altid parat til at overstrømme det intellektuelle liv og til at bevirke en pludselig omstyrtning af den evolution, som vi var så stolte af: fra følelse til tanke, fra følelsessprog til artikuleret sprog..."11

9 Febvre, 1941:7-8.

10 Febvre, 1941:8.

11 "il y a, en chacun de nous, de vie émotionnelle toujours prête à déborder la vie intellectuelle et pour opérer un brusque renversement de cette évolution dont nous étions si fiers: de l'émotion à la pensée, du langage émotionnel à langage articulé...” Febvre, 1941:19. 
Følelserne var tilsyneladende igen ved at få overtaget over intellektet, og det med tragiske konsekvenser. Historikere skulle således studere følelser, fordi de havde spillet - og fortsat kunne spille - en afgørende og potentielt katastrofal rolle i den historiske udvikling. ${ }^{12}$

Denne forståelse af følelser har en del tilfælles med den, man finder i den tyske sociolog Norbert Elias' klassiske værk Über den Prozeß der Zivilisation, som han udgav to år inden, Febvres manifest udkom. Elias argumenterede blandt andet for, at den vestlige civiliseringsproces indebar en stigende (selv)kontrol af det menneskelige følelsesliv. Mens de brede masser i den europæiske middelalder var karakteriseret ved spontane følelsesudtryk og de voldelige passioners frie løb, medførte moderniteten en øget regulering af følelsesudtryk. ${ }^{13}$

At Febvre og Elias anså det for meningsfuldt at undersøge følelser i fortiden betød ikke, at de opfattede følelser som decideret historiske. Den amerikanske historiker Barbara Rosenwein har argumenteret for, at begges forståelse af følelser er kendetegnet ved en "hydraulisk" model. ${ }^{14}$ I en hydraulisk model er følelser i bund og grund naturlige fænomener, der har deres udspring i det menneskelige indre. De kan vælde op og overvælde mennesket, eller deres udtryk kan styres eller kanaliseres gennem individuelle eller sociale og kulturelle foranstaltninger, men de er ikke i sig selv foranderlige.

Selvom man kan stille spørgsmålstegn ved, om Febvre og Elias fremstiller følelser helt så uforanderlige, som Rosenwein hævder, har de to tænkere ikke teoretiseret kvalitative følelsesmæssige ændringer over tid. ${ }^{15}$ De beskrev først og fremmest følelser som noget naturgivent, universelt og i kroppen iboende, som kunne bryde ud eller styres. Som den følgende diskussion vil vise, finder man i

12 Barbara Rosenwein kalder af samme grund Febvres artikel for politisk videnskab i forklædning. Rosenwein, 2002:823. For en diskussion af, hvordan Lucien Febvre kan inspirere nutidens følelseshistorikere, se Dixon, 2011.

13 Elias, 2000, fx s. 236-256 og 397-414. En af det 19. århundredes store sociologer, Emile Durkheim, havde en lignende forståelse af "passioner": de var individuelle, naturlige og i udgangspunktet styrende for menneskelig adfærd. For Durkheim var kontrol af passionerne imidlertid ikke kun en historisk proces, men derimod en uadskillelig del af et hvilket som helst samfund. Durkheim anså den kontrol, som det sociale fællesskab påførte følelserne, for frisættende. Mens "passioner" individualiserede, gjorde de også mennesket til slave. Jo mere mennesket var i stand til at frigøre sig fra sine passioner, desto mere kunne intellektet eller "ideerne" komme til sin ret. Durkheim, 2001:201. Durkheim skelnede imidlertid mellem passioner og følelser. Mens passionerne stod i modsætning til intellektet, kunne følelser uddannes - og ifølge Durkheim var al opdragelse et forsøg på at lære barnet at "se, føle og handle" på måder, barnet ikke spontant kunne være nået frem til. Durkheim, 1982:6.

14 Rosenwein, 2002.

15 Begge åbner implicit for, at følelser også kan kultiveres. I sit essay beskriver Febvre således, hvordan mennesker kan fremmane og dirigere følelser gennem ritualer osv. Dertil kommer, at han fremhæver mange forskelligartede følelseskulturer i forskellige geografiske, religiøse og historiske kontekster. For Elias var skam eksempelvis en følelse, der voksede frem i civiliseringsprocessen og som led i reguleringen af passionerne. Følelseslivet var derfor måske ikke helt så uforanderlige for Febvre og Elias, som Rosenwein hævder. 
Febvres og Elias' værker kimen til mange af de teoretiske udfordringer og brydninger, der præger den nyere følelseshistorie.

\section{Følelse \& intellekt}

En af de problematikker, som siden Febvre og Elias har sat sit præg på følelseshistorien, er modsætningsparret følelse og intellekt.

De fleste nyere bidrag har forsøgt at gøre op med dette modsætningspar. Inspireret af kognitive psykologer, som beskriver følelser som en form for erkendelse, anfører filosoffen Robert Solomon eksempelvis i en artikel fra 1988, at følelser skal forstås som et system af domme (judgments). ${ }^{16}$ Det må dog ikke forstås sådan, at en følelse er det samme som en konklusionen på et logisk ræsonnement. En følelse er derimod ifølge Solomon en kognitiv reaktion ikke alene på en bestemt handling, men også på de omstændigheder, handlinger og relationer, der omkranser og definerer den. Han udvikler derfor Aristoteles' betegnelse af vrede som erkendelsen af fornærmelse eller krænkelse således: ”Anger is not just a judgment of offense but a network of interlocking judgments concerning one's status and relationship with the offending party, the gravity and the mitigating circumstances of the offense and the urgency of the revenge."17 Solomon forsøger kort sagt at nedbryde skellet mellem følelse og intellekt ved at vise, at den ene er flettet ind i den anden.

Foucault-inspirerede tænkere har haft en anderledes tilgang til problematikken: nemlig at vise, hvornår og hvordan følelse og fornuft begyndte at blive opfattet som hinandens modsætninger. I sin undersøgelse af fædrelandskærlighed som subjektiveringsstrategi, som jeg vil diskutere nedenfor, argumenterer Tine Damsholt således for, at "senere tiders opfattelse af fornuft og følelse som to modsatrettede kategorier, hvor mere fornuft betyder mindre følelse og omvendt," er en arv fra Romantikken. ${ }^{18}$

I den erkendelsesinteresse, der omhandler de historiske og kulturelle processer, som producerer følelser som menneskets kerne, følger Damsholt blandt andre antropologerne Lila Abu-Lughod \& Catherine Lutz, som også argumenterede for, at den nutidige opfattelse af følelser som individets sande kerne og fornuftens modsætning var en konsekvens af specifikke historiske og kulturelle processer. ${ }^{19}$ Til forskel fra på den ene side Febvre og på den anden side kognitive psykologer og tænkere som Solomon ønskede Abu-Lughod \& Lutz således ikke én gang for alle at definere relationen mellem følelse og fornuft. Ved at pege på de historiske

16 Solomon, 1988.

17 Solomon, 1988: 186.

18 Damsholt, 2004:7.

19 Abu-Lughod and Lutz, 1990:6. 
processer, hvorigennem den gængse forståelse af følelse og fornuft som hinandens kontraster er blevet til, ønsker de derimod at afnaturalisere modsætningen.

Med et lignende greb argumenterer den engelske historiker Thomas Dixon i sin bog From Passions to Emotions for, at begrebet "emotions" ikke er ældre end 200 år. Bogen er en undersøgelse af fremvæksten af "emotion" som en psykologisk kategori defineret i kontrast til rationalitet. Mens "emotions” i løbet af det 19. århundrede vandt frem som en overordnet kategori for alle mentale fænomener, blev den tidligere og langt mere nuancerede typologi med begreber som appetit, passion, affekt og sensibilitet gradvist tilsidesat.

Frem for at samle hele dette spektrum af mentale fænomener med forskellige relationer til rationaliteten under én betegnelse mener Dixon, at vi bør vende tilbage til en mere nuanceret typologi: "I will suggest that a more differentiated typology would be a useful tool, and would help us to avoid making sweeping claims about all 'emotions' being good or bad things, rational or irrational, virtuous or vicious." 20

Dixon vil således ved hjælp af en genealogisk analyse vise emotionskategoriens historicitet. Som citatet antyder, vil han dog mere end det: han vil med inspiration i tidligere tiders begrebsliggørelse berige nutidens måde at tænke og forstå det mange facetterede menneskelige følelsesliv på.

Selvom forsøgene på teoretisk at nedbryde og historisere skellet mellem fornuft og følelse således har været forskelligartede, synes der blandt de fleste tænkere at være konsensus om, at det modsætningspar, Febvre opererede med, er misvisende og problematisk.

\section{Følelser som kulturelle produkter}

Vi tror, at følelser er uforanderlige? Men alle følelser, og særligt de, som forekommer mest noble og mest upartiske [désintéressés], har en historie. ${ }^{21}$

Michel Foucault, 1971

Det nok mest centrale omdrejningspunkt inden for den nyere følelseshistorie har været spørgsmålet om, i hvilken grad følelser er socialt og kulturelt konstituerede.

I en meget indflydelsesrig artikel fra 1985 argumenterer Carol \& Peter Stearns for, at følelseshistorikere må skelne mellem det, de kalder et samfunds emotionologi (emotionology) og de individuelle, indre følelser. Forskere kan ifølge Stearns \& Stearns reelt kun undersøge det historiske samfunds emotionologi, hvilken de definerer således:

20 Dixon, 2003:2.

21 "Nous croyons à la pérennité des sentiments? Mais tous, et ceux-là surtout qui nous paraissent les plus nobles et les plus désintéressés, ont une histoire." Foucault, 1971:159. 
the attitudes that a society or a definable group within society maintains toward basic emotions and their appropriate expression; ways that institutions reflect and encourage these attitudes in human conduct...22

Forfatterne mener, at samfundets emotionologi givetvis påvirker individers følelser (i det mindste deres udtryk), men at historiske analyser må sondre klart mellem de to ting. Selv koncentrerer de sig om at undersøge udviklingen i emotionologier, hovedsageligt gennem vejlednings- og etikettelitteratur. ${ }^{23}$ De forfægter med andre ord en skelnen mellem samfund og individ og indre og ydre, der ligner den, Febvre og Elias opererede med. Som den tyske historiker Margrit Pernau påpeger, er det endvidere uklart, om Stearns \& Stearns mener, at individets indre følelsesliv er foranderligt, eller om det kun er emotionologien, dvs. de sociokulturelle standarder eller normer, der er det. ${ }^{24}$

Den artikel, Peter Stearns seks år senere sammen med Timothy Haggerty udgav om brug af frygt i børneopdragelse i USA i perioden 1850-1950, kan ses som et eksempel på operationalisering af emotionologibegrebet i en konkret historisk undersøgelse. På baggrund af en analyse af amerikanske opdragelsesvejledninger henvendt til middelklasseforældre samt forskellig slags litteratur til børn argumenterer forfatterne for, at der skete en overordnet udvikling i den generelle holdning til frygt i barndommen. På intet tidspunkt i den periode, de behandler, blev brug af frygt opfattet som et acceptabelt opdragelsesinstrument i den amerikanske middelklasse. Men efter 1900 var der ifølge forfatterne øget fokus på det ubehag, der var forbundet med frygt, og opdragelsesmanualerne lagde derfor mere vægt på at undgå frygt i børneopdragelse. Manualerne kan således bruges som kilde til middelklassens opfattelser af, hvad der udgjorde et ønskeligt følelsesliv. $^{25}$

Da forfatterne understreger, at forældre givetvis langt fra altid fulgte vejledningernes råd, vedrører analysens konklusion middelklassens kulturelle normer for frygt, snarere end forældrenes egentlige praksis eller den generelle udbredelse af frygt blandt middelklassens børn. Selvom forfatterne i artiklen hævder, at frygt er en "kulturel konstruktion", 26 opererer de, lige som Stearns \& Stearns med en sondring mellem den subjektive oplevelse og samfundsmæssige standarder (eller emotionologi). Og mens de også synes at antage, der er et forhold mellem de to, undgår de nøjagtigt at identificere denne relation.

\footnotetext{
22 Stearns and Stearns, 1985:813.

23 For et nyere bud på en mere udvidet brug af vejlednings-og etikettelitteratur, se Pernau, 2012.

24 Pernau, 2012:120. I artiklen argumenterer Pernau for, at anvisningslitteratur kan bruges som kilder til mere end emotionologier: de er også et udtryk for samtidens følelsesbegreber og dermed til spektret af mulige følelsesoplevelser.

25 Stearns and Haggerty, 1991:64.

26 Stearns and Haggerty, 1991:64.
} 


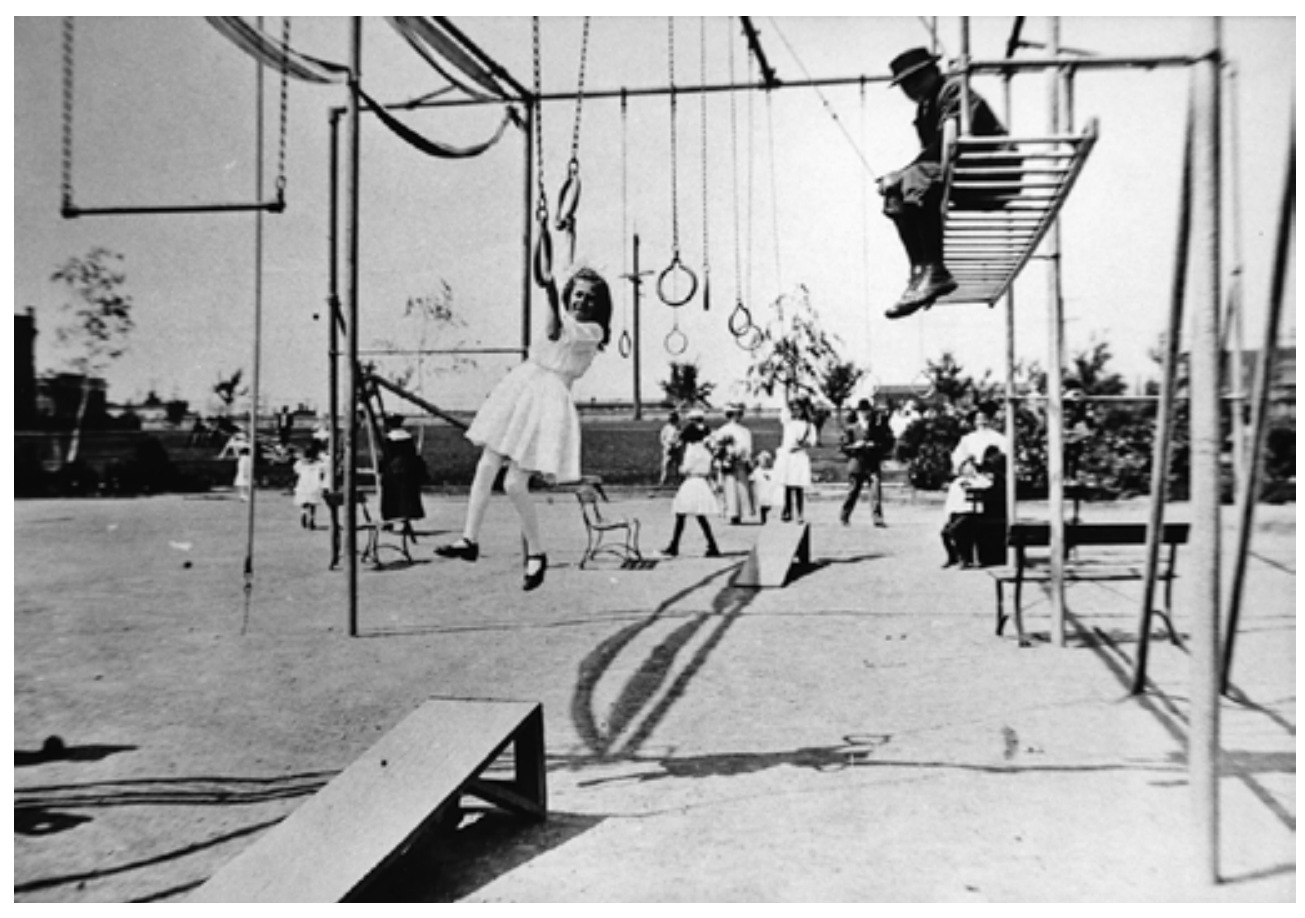

Legende børn på Broadway Playfield i Seattle, Washington, 1910. Ifølge Haggerty og Stearns var det ikke god skik at bruge frygt som opdragelsesinstrument i middelklassens USA i denne periode. Foto: Seattle Municipal Archives.

Omkring samme tid som Stearns \& Stearns' artikel udkom, forsøgte flere antropologer at gøre op med dikotomierne samfund/individ, normer/oplevelse og indre/ ydre, som, de mente, havde struktureret kulturanalytiske og historiske studier af følelser på uhensigtsmæssig vis. I en artikel fra 1984 anfører antropologen Michelle Rosaldo for eksempel, at følelser (hun bruger både begreberne feelings og affects) skulle forstås som en slags kropsliggjorte tanker, der var skabt gennem kulturelle processer. "Affects", skriver hun:

"Are no less cultural and no more private than beliefs. They are instead, cognitions - or more aptly, perhaps, interpretations - always culturally formed, in which the actor finds that body, self, and identity are immediately involved."27

For Rosaldo er følelser ikke indre, universelle og biologisk funderede fænomener, sådan som Febvre og Elias tænkte dem, men derimod kulturelt skabte størrelser, der bliver formet og omformet gennem sociale processer. ${ }^{28}$ Inden for denne forståelsesramme giver det ikke mening at skelne skarpt mellem individ og samfund,

27 Rosaldo, 1984:141.

28 For lignende antropologiske begrebsliggørelser af følelser, se Lutz and White, 1986; Abu-Lughod and Lutz, 1990. 
indre og ydre eller krop og sind i forbindelse med følelser. Og selvom Rosaldo anerkender, at det i sidste ende måske ikke er muligt helt at undgå modsætningsparret natur/kultur, må kulturanalyser koncentrere sig om de elementer af tilværelsen (herunder følelseslivet), der er kulturelt konstituerede. ${ }^{29}$

I sin artikel om skam blandt Ilongothovedjægere i Flippinerne udarbejdet på baggrund af eget feltarbejde benytter Rosaldo sig også af en sådan følelsesdefinition. Her argumenterer Rosaldo for, at følelsen skyld slet ikke findes i Ilongotkultur. Skam findes, men har en helt anden karakter end i den vestlige kultur. I vesten kender vi ifølge Rosaldo skyld og skam som følelser, der regulerer og dæmper selvets problematiske impulser: seksuelt begær, vold osv. Ilongotfolkets skam er derimod, kort fortalt, en følelse, der forudser, begrænser eller erstatter opvisning af vrede. Skam kan også være en kropslig erkendelse af mindreværd i en konkret relation og en motiverende faktor til at ændre på en given situation. ${ }^{30}$

Det er ikke helt klart, hvordan eller hvorfor Rosaldo identificerer denne følelse som skam. Hendes pointe er dog ikke, at der er lighed mellem vestligt og Ilongot følelsesliv, men derimod at der er basale forskelle, som ikke bare er et spørgsmål om forskellige normer for følelsesudtryk. I stedet skyldes forskellene mellem vestligt og Ilongot følelsesliv fundamentalt uens forhold mellem den enkelte og samfundet. Mens den vestlige individualisme ifølge Rosaldo indebærer en opfattelse af individet som præget af en konflikt mellem indre drivkræfter, der udgør dets essens, og samfundets normer, har Ilongotfolket helt andre ontologiske antagelser. De opererer ikke med en grundlæggende forskel mellem individ og samfund, og den enkelte hovedjæger stræber ikke efter individualisering, men derimod efter at blive en del den sociale enhed. ${ }^{31}$ Derfor er det i den kulturelle kontekst heller ikke meningsfuldt at skelne skarpt mellem ydre, sociale normer (eller emotionologi) og indre oplevelse (eller selvet) i følelseslivet.

Med inspiration i blandt andre Michelle Rosaldos forståelse af følelser argumenterer David Sabean og Hans Medick i deres socialhistoriske antologi om familieliv fra 1984, Interest and Emotion, også for, at følelseslivet grundlæggende er socialt og kulturelt formet: "Emotions are socially constituted and are not only the expression of experience but also the determinants of experience and practice." 32 Heller ikke for disse forfattere er der tale om et tydeligt skel mellem sociale normer og individuelle følelser. Selvom det sociokulturelle implicerer de individuelle følelser, mener forfatterne altså, at der også er en slags tilbagevirken fra det individuelle til det sociale: at følelsesbestemte praksisser påvirker det sociale. 
Mere konkret forsøger forfatterne at gøre op med en forenklet fortælling om, at familien gennem historien er gået fra at være en økonomisk funderet enhed til at være et fællesskab formet af emotionelle behov samt en tilhørende forestilling om, at middelklassefamilien er følelsesbetonet, mens arbejderfamilien er økonomisk struktureret. Materielle interesser og følelser skal i stedet ses som kulturelt ordnede elementer, der indgår i komplekse gensidige relationer i alle former for familieliv, om end på skiftende måder over tid og rum. ${ }^{33}$

Ud fra et foucauldiansk perspektiv argumenterer den danske etnolog Tine Damsholt i en artikel fra 2004 ligeledes for et følelsesbegreb, der har en del tilfælles med Rosaldos. "Følelser," skriver Damsholt, ”er kulturelle produkter, men de reproduceres i det enkelte individ som legemliggjort erfaring." ${ }^{4}$ Følelser har med andre ord ikke, som for Febvre, deres oprindelse i et universelt individs organisme, men bliver derimod så at sige installeret i mennesket gennem diskurser, institutionelle praksisser og kropslige ritualer. Damsholts fokus er på de kulturelle processer, der producerer følelserne og får dem til at fremstå som individets naturlige kerne.

Som eksempel argumenterer Damsholt for, at fædrelandskærlighed i slutningen af 1700-tallet (som ellers ofte opfattes som rationalismens tidsalder) var et kerneelement i de kontinuerlige subjektiveringsprocesser. Den moderne europæiske stat og ikke mindst militæret opererede med en "governmental" ledelsesstrategi baseret på "trang” i stedet for "tvang". ${ }^{35}$ Snarere end at opfatte det som et ydre krav eller en sur pligt skulle de moderne borgere ønske at ofre sig for fædrelandet. Gennem blandt andet litteratur, gymnastiske øvelser og ritualer blev patriotisme produceret og reproduceret i borgerne. Individet var aktivt involveret og blev til et subjekt i processen, men var, som Damsholt skriver, ikke selv "opfinder” af følelserne: ”Der produceres bag om ryggen på de involverede en kulturel matrix for, hvordan følelser opleves og genkendes." ${ }^{36}$ Det følende individ har i denne Foucaultinspirerede optik ingen før-kulturel eller prediskursiv eksistens. Den kulturelle matrix fremstår som determinerende for det enkelte menneskes følelsesliv.

33 Medick and Sabean, 1984a. Selvom begrebet "emotion" indgår i titlen på antologien, synes følelser ikke at være det mest centrale emne for redaktørerne, som i højere grad er interesserede i forholdet mellem kulturelle normer (herunder følelser), økonomi og sociale relationer. I deres anvendelse flyder begrebet "emotion" ofte ind i andre begreber som mening/betydning eller kvalitet af sociale relationer.

34 Damsholt, 2004:6. Inspirationen er også hentet i Abu-Lughod and Lutz, 1990, særligt s. 12.

35 Damsholt, 2004:16.

36 Damsholt, 2004:11. Damsholt har siden udviklet analysen i et studie af statsborgerskabsceremonier i forskellige vestlige lande. Ved hjælp af en genealogisk tilgang viser hun her, hvordan man i forskellige nationale kontekster - og i det 18. århundrede såvel som i begyndelsen af det 21. århundrede - har bestræbt sig på at fostre patriotiske borgere gennem sanselige ceremonier. Damsholt, 2008. 
Til forskel fra Stearns \& Stearns søger Rosaldo, Medick \& Sabean og Damsholt således i hver deres bidrag at nedbryde skellet mellem individet og det sociale i studiet af følelser. Den enkeltes følelsesliv skal ifølge disse tænkere ikke forstås ud fra universelle indre biologiske eller psykologiske træk, men må undersøges i relation til de konkrete sociale og kulturelle konstellationer, der former individets erkendelse og oplevelse. Man kan sige, at disse forskellige tilgange er kendetegnet ved, at de, som Michel Foucault gjorde i citatet ovenfor, inkluderer følelser i et historiserende paradigme. De hævder og forsøger konkret at vise, at følelser på samme måde som andre fænomener, man en gang opfattede som naturgivne, også er kulturelt konstituerede.

\section{Søgen efter en dynamik: emotiver og affekt}

De socialkonstruktivistiske og poststrukturalistiske følelsesforståelser og de ontologiske og epistemologiske præmisser, de bygger på, har vakt markante reaktioner inden for de seneste årtier. I 1997 udgav William Reddy den skelsættende artikel “Against Constructionism. The Historical Ethnography of Emotions”. Til trods for artiklens titel står Reddy i gæld til socialkonstruktivistisk teori, idet han medgiver, at følelser er delvis kulturelt formede. Han mener dog ikke, at følelser til fulde kan forklares ud fra kulturelle processer. Reddys primære kritik af socialkonstruktivismen består i, at den efter hans overbevisning ikke anviser en dynamik, der kan forklare forandringer i følelseslivet over tid. Paradoksalt nok forsøger socialkonstruktivistiske tænkere, netop ved at påpege følelsernes sociokulturelle konstituering, at fremdrage deres foranderlighed i kontrast til tidligere opfattelser af følelser som universelle, biologisk funderede og ahistoriske fænomener, men ifølge Reddy har socialkonstruktivismen ikke formået at identificere forandringens væsen eller årsag: “A coherent account of emotional change must find a dynamic, a vector of alteration, outside the discursive structures and normative practices that have monopolized ethnographic attention." 37

Med begrebet emotiver (emotives) forsøger Reddy at identificere netop en sådan dynamik. Emotiver er følelsesytringer, som hverken er rent performative (som enten opfører eller konstruerer en følelse) eller rent konstative (som blot konstaterer eller rapporterer en allerede eksisterende følelse). I stedet skal følelsesytringer forstås som noget midt imellem: et søgende udtryk, der fanger et vagt og endnu ikke formet følelsesmateriale, men som dermed er med til at give form til, styrke og ændre materialet: ”Emotives are influenced directly by and alter 
what they refer to." 38 Hvis man for eksempel bliver spurgt, om man er vred, er det sandsynligt, at man bliver mere vred ved at svare "ja” og mindre vred ved at svare "nej".

Begrebet emotiver indebærer også, at sociale og kulturelle processer ikke fuldstændigt determinerer følelseslivet: der findes et (natur)givent materiale situeret $\mathrm{i}$ individets krop, som sætter betingelser for disse processer.

Reddys teoretisering bygger på samme skelnen, som Stearns \& Stearns lægger til grund for deres emotionlogi-begreb, nemlig den mellem kulturelle standarder eller normer (det ydre) og de individuelle oplevede (indre) følelser. ${ }^{39}$ Men mens Stearns \& Stearns fokuserer på at undersøge de kulturelle normer, introducerer Reddy emotiver i et forsøg på at teoretisere et bindeled mellem de to. ${ }^{40}$

Et andet bidrag, som har haft stor indflydelse, ikke mindst inden for kultur- og mediestudier, er Brian Massumis affektteori. ${ }^{41}$ Inspireret af Gilles Deleuze definerer Massumi affekt som en autonom intensitet, som på et for individet ubevidst plan passerer fra én krop til en anden. ${ }^{42}$

Massumi hævder, at den poststrukturalistiske tilgang til følelser - og til kroppen mere generelt - har reduceret kroppen, og hermed kroppens evne til sansning og affekt, til en position på et altomfattende kulturelt net. Fordi kroppen forstås som fuldstændigt kulturelt eller diskursivt konstitueret, mener Massumi (ikke ulig Reddy, som han dog ikke refererer til), at den slags kulturanalyse mangler et forandringselement: "The very notion of movement as qualitative transformation is lacking." ${ }^{43}$ Ifølge Massumi kan variationer over tid eller rum inden for poststrukturalismen kun forklares med ændret "positionalitet”, dvs. med reference til individers forskellige eller forandrede positioner på det kulturelle net. Der er ikke noget i poststrukturalismen, der kan forklare forandring af selve nettet. I Massumis gengivelse er poststrukturalistisk teori således en særdeles deterministisk teoriformation, der fremstiller kultur som statisk. ${ }^{44}$

Massumi introducerer affekt som den forandringsvektor, socialkonstruktivismen og poststrukturalismen efter hans mening fattes: “Actually existing, struc-

38 Reddy, 1997:331. Der er visse ligheder mellem Reddys emotiver og lan Hackings "looping effect" teori, inden for hvilken kategorisering ( $f x$ af mennesker) også er med til at give form til et eksisterende potentiale. Dynamikken ligger i den kontinuerlige udveksling mellem det givne potentiale og den kulturelle repræsentation Hacking, 1995.

39 For en sammenligning og diskussion af Peter Stearns', William Reddy's og Barbara Rosenweins teoretiske bidrag til følelseshistorie, se Plamper, 2010.

40 Artiklen vakte en livlig debat og mange svar til Reddy fra andre forskere blev trykt i samme nummer af tidsskriftet. I Reddy, 2001 uddyber og videreudvikler Reddy begrebet.

41 For en interessant diskussion af både Massumi og en anden affektteoretiker, Eve Kosofsky Sedgwick, hvis teori har været meget indflydelsesrig særligt inden for queerstudier, se Frederiksen, 2012. Med fokus på skam giver artiklen også et godt overblik over de vigtigste teoretikere og største brydninger inden for affektstudier mere generelt.

42 Massumi, 2002.

43 Massumi, 2002:3.

44 Massumi, 2002:3. 
tured things live in and through that which escapes them. Their autonomy is the autonomy of affect." ${ }^{45}$ Mens følelser (emotions) er bevidste, formede og tilgængeligt gennem sprog og kultur, ${ }^{46}$ er affekt ikke-struktureret. Som kulturforskeren Mons (Maja) Bissenbakker Frederiksen formulerer det, er affekt for Massumi "autonom intensitet, som undslipper fastfrysning i diskursive kategorier". ${ }^{47}$

Alligevel er den ontologiske status af affekt i relationen mellem individet og det sociale noget tvetydig i Massumis fremstilling. Er måden, hvorpå kroppe påvirker hinanden gennem affekt, universel og ahistorisk? Eller bliver affektive dispositioner forankret i individet gennem kulturelle processer? Massumi skriver, at affekt er "unformed and unstructured, but ... nevertheless highly organized and effectively analyzable...". ${ }^{48}$ Samtidig hævder han, at affekt ikke er førsocialt: "it includes social elements but mixes them with elements belonging to other levels of functioning and combines them according to different logic". ${ }^{49}$

Med sådanne flertydige sætninger undgår Massumi at definere det nøjagtige forhold mellem affekt og sociale strukturer: affekt er på én og samme tid ustruktureret/autonomt og stærkt organiseret/indeholdende sociale elementer. At kroppen, hvorigennem affekt opererer, desuden ifølge Massumi indfolder (infolds) kulturelle kontekster og viljer (volitions), mudrer billedet yderligere. ${ }^{50}$

Mens der for Massumi synes at være er en gensidig, men uspecificeret relation mellem affekt og det sociokulturelle, er det Massumis insisteren på affekts autonomi, der har vakt mest genklang inden for nyere affektstudier. Som kønsforskeren Claire Hemmings skriver i en kritik af Massumi og Eve Kosofsky Sedgwick, er interessen for affektteori udtryk for en utilfredshed med poststrukturalistiske magtteoriers fokus på sociale strukturer frem for mellemmenneskelige relationer som formende for individets følelsesliv. ${ }^{51}$ Ifølge Hemmings forstår flere affektteoretikere de poststrukturalistiske kulturstudier som en kontinuerlig og dræbende (gen)opdagelse af magt overalt: "prohibition where it appeared there was freedom, prohibition in a space we had not, until now, thought to look." 52 Inden for dette perspektiv, bliver den påståede poststrukturalistiske mangel på dynamik decideret deprimerende. Hvis alt allerede er struktureret, bliver det svært at se, hvorfra det, der kan underminere magten og omforme de sociale strukturer, skal kunne udspringe. Autonom affekt står derfor som løsningen: som det aspekt af

\footnotetext{
45 Massumi, 2002:35.

46 "It is intensity owned and recognized." Massumi, 2002:28.

47 Frederiksen, 2012:6. Kursiv i original.

48 Massumi, 2002:260. Fodnote 3.

49 Massumi, 2002:30. Oprindelig kursiv.

50 Massumi, 2002:30. Den samme tvetydighed gør sig gældende i megen Massumi-inspireret kulturanalyse. Se fx antologien Clough and Halley, 2007.

51 Hemmings, 2005:548-49. Claire Hemmings diskuterer også Eve Kosofsky Sedgwicks værk Touching Feeling (2003).

52 Hemmings, 2005:553.
} 
menneskelivet, der undslipper de sociokulturelle magtmønstre og derfor kan underminere dem.

Som Hemmings viser, karikerer Massumi i nogen grad poststrukturalismen og socialkonstruktivismen. ${ }^{53}$ Mange poststrukturalistiske tænkere har netop søgt at teoretisere forandring i en reaktion på strukturalismens påståede mangel på samme, hvilket Massumi ikke forholder sig til i nogen nævneværdig grad. Det er endvidere påfaldende, at Massumi ikke går i direkte dialog med konkrete analytikere, men angriber hvad der må siges at være en radikal diskursteoretisk tilgang, som de færreste har anvendt.

En af de forskere, der har ladet sig inspirere af Massumi, og som netop fremhæver autonomien som det vigtige og afgørende, er kommunikationsforskeren Eric Shouse. Hans forklaring af relationen mellem affekt og det sociale er noget mere firkantet og derfor mindre tvetydig end Massumis. Shouse anfører, at affekt i modsætning til følelser (emotions, feelings), som er kulturelt lærte og sprogligt tilegnede, er noget ustruktureret og ubevidst, der ikke kan (be)gribes med sprog. Med et empirisk eksempel forklarer Shouse, at spædbørn ikke har følelser (emotions, feelings), kun affekt:

"An infant has no language skills with which to cognitively process sensations, nor a history of previous experiences from which to draw in assessing the continuous flow of sensations coursing through his or her body. Therefore, the infant has to rely upon intensities (a term that Massumi equates with affect)." 54

At spædbarnet, som Shouse synes at opfatte som en slags sociokulturel tabula rasa, er begavet med kapaciteten for affekt, men ikke for følelser, tydeliggør, at affekt i hans forståelse kommer forud for sociokulturelle strukturer. ${ }^{55}$

Denne definition minder på mange måder om Febvres forståelse af følelser. Han mente også, at affekt havde sin rod i kroppen, at det kunne smitte fra en krop til en anden, og at det stod i modsætning til det socialt konstituerede intellekt. En sådan definition af affekt indebærer i sidste instans ahistoricitet.

Man kan, som Rosaldo gør i sin artikel fra 1984, stille spørgsmålstegn ved, om det, der ligger uden for kulturen og det sociale, i det hele taget er kulturanalytikerens eller historikerens område. Massumis affektteori har da heller ikke vundet

53 Imidlertid synes Hemmings også i nogen grad at forenkle Massumis affektbegreb, idet hun beskriver det autonomt, førlinguistisk, prækulturelt og ikke forholder sig til de steder, hvor Massumi om end tvetydigt og ret uklart forsøger at teoretisere relationen mellem det affektive og det kulturelle.

54 Shouse, 2005. Kursiv i original.

55 Man kan stille spørgsmålstegn ved, om spædbarnet i det hele taget bør opfattes som en tabula rasa, idet man kan argumentere for, at den sociokulturelle påvirkning begynder allerede i de tidligste fosterstadier. 
særligt stor indpas inden for den historiske forskning. Men i det omfang et Massumiinspireret affektbegreb er nyttigt for følelseshistorikere, må det være netop relationen mellem affekt og det kulturelle, der er interessant. Kun for så vidt, at affekt interagerer med det sociokulturelle på en måde, som vi kan analysere, forekommer det dels at kunne udgøre den efterstræbte forandringsvektor, dels at være tilgængeligt og relevant for historikere og kulturanalytikere. Med Hemmings' ord: "Affect might in fact be valuable precisely to the extent that it is not autonomous." 56

Opsummerende kan man sige, at mens de socialkonstruktivistiske og poststrukturalistiske tænkere inkluderede følelser og affekt i det korpus af kulturelt konstituerede elementer i tilværelsen, som kunne dekonstrueres og historiceres, insisterer mange affektteoretikere på, at affekt er autonomt og ustruktureret og dermed både frigørende og årsag til kulturelle forandringer. Massumi og andre affektteoretikere har dog ikke nøjagtigt teoretiseret relationen mellem det affektive og det kulturelle, og i visse bidrag kommer affekt til at fremstå som decideret prækulturelt, universelt og ahistorisk.

\section{Følelser som socialt konstituerede og historisk foranderlige}

For Reddy er det netop interaktionen mellem det endnu uformede potentiale og det bevidstgjorde følelsesliv, der er interessant, og som han med emotivbegrebet forsøger at teoretisere. Et andet nyere bud, der hurtigt er blevet populært blandt følelseshistorikere, er begrebet følelsespraksisser, som Monique Scheer introducerede i en artikel i 2012. Akkurat som Massumi og andre affektteoretikere ønsker Scheer at sætte kroppen tilbage i centrum for studiet af det menneskelige følelsesliv. I modsætning til Febvre forstår hun ikke kroppen som en biologisk funderet, universel størrelse, der producerer ahistoriske følelser.

Med inspiration i Pierre Bourdieus teorier om kropsliggjorte sociale strukturer (habitus) hævder Scheer i stedet, at kroppen bliver formet og omformet i de forskellige sociokulturelle kontekster, som den bevæger sig i igennem livet. Følelser skal ifølge Scheer forstås som en slags praksisser, der udspringer fra den socialt strukturerede krop. At forstå følelser som praksisser, skriver hun, "means understanding them as emerging from bodily dispositions conditioned by a social context, which always has cultural and historical specificity." ${ }^{57}$ Denne definition trækker på Bourdieu, men harmonerer også fint med tidligere antropologiske teorier om følelser. Følelsespraksisbegrebet kan eksempelvis ses som

56 Hemmings, 2005:565. Hemmings fremførte kritikken mod Massumi (og til dels Eve K. Sedgwick).

57 Scheer, 2012:193. Denne teoretisering minder om Massumis udsagn om, at kroppen indfolder kulturelle kontekster og viljer. 
en videreudvikling af Michelle Rosaldos ovennævnte beskrivelse af følelser som kropsliggjorte tanker.

Bevidst om kritikken af socialkonstruktivistiske følelsesteoriers manglende forandringsvektor forsøger Scheer med praksisbegrebet imidlertid mere målrettet at identificere et princip for foranderlighed i følelseslivet. Følelsespraksisser skal forstås som på én og samme tid spontane og styrede af indlejrede dispositioner. Selvom de udføres af den socialt formede krop, er de ikke fuldstændigt dikterede af de sociale strukturer. De kropsliggjorte sociale strukturer specificerer ifølge Scheer, hvad der kan føles i en given situation på et givent sted, men de determinerer ikke de konkrete følelser: "Emotions can thus be viewed as acts executed by a mindful body, as cultural practices." 58

Scheers teori kan tolkes sådan, at mens individets praksis i vid udstrækning er struktureret af de sociale kontekster, der har formet kroppen, er dets praksis samtidig et bidrag til den konkrete kontekst, inden for hvilken han eller hun befinder sig. Deri består forandringspotentialet. ${ }^{59}$

Følelsespraksisser er ifølge Scheers definition "strategiske”: de kan være mobiliserende og regulerende, og kan være rettet mod én selv eller andre. Men i modsætning til Massumis forsøg på at skelne mellem det autonome og bevidstgjorte i følelseslivet, ønsker Scheer ikke at definere følelsespraksisser som enten bevidste eller ikke-bevidste. Hun hævder derimod, at disse praksisser befinder sig på et kontinuum mellem det bevidste og det ikke-bevidste, og at de kan være mere eller mindre intentionelle. ${ }^{60}$

Mere konkret skriver Scheer: "Emotional practices are habits, rituals, and everyday pastimes that aid us in achieving a certain emotional state. This includes the striving for a desired feeling as well as the modifying of one that is not desirable." ${ }^{61}$ Denne specificering gør det klarere, hvad vi skal lede efter, hvis vil undersøge følelsespraksisser: nemlig verbale udsagn ("jeg elsker dig”, ”er det ikke urimeligt, at ...?”) eller kropslige udtryk (gråd, smil, gåsehud) og handlinger.

Det er imidlertid sigende, at denne mere konkrete definition af følelsespraksisser indebærer en genintroduktion af følelse som en tilstand (emotional state), der ikke er nærmere afklaret. Definitionen efterlader endvidere spørgsmålet om, hvordan følelsespraksisser adskiller sig fra andre praksisser. Hvis følelsespraksis-

58 Scheer, 2012:205.

59 I en kommende artikel argumenterer jeg for, at begrebet følelsespraksisser produktivt kan videreudvikles i en dialog med Arlie Hochschilds begreb "emotional labor", som også refererer til mobilisering, håndtering og regulering af følelser, men som i højere grad understreger det produktive element $i$ sådanne bestræbelser. Konkret er Hochschild endvidere interesseret $i$ at påpege den markedsværdi, der ligger i følelsesarbejde (fx eksemplificeret ved stewardessens smil), hvilket også gør hendes teori relevant for økonomisk/socialt orienteret historie. Se Hochschild, 2012, særligt s. 1-23.

60 Scheer, 2012:207.

61 Scheer, 2012:209. 
ser kan være ubevidste, er det svært at se, hvilke udsagn og handlinger, der ikke er følelsespraksisser, idet alle praksisser vel må siges at påvirke individets egne eller andres følelser. Scheer synes at antage, at hun og artiklens læsere deler en forståelse af, hvad der adskiller følelser fra andre praksisser, og at hun derfor ikke behøver at definere det mere præcist. Dette efterlader igen følelsernes ontologiske status noget sløret.

Scheers begreb er derfor måske ikke en færdig løsning på den teoretiske udfordring med at formulere et følelsesbegreb, der både teoretiserer følelseslivets sociale konstituering og anviser et forandringsprincip. Alligevel mener jeg, at det er et nyttigt begreb, ikke mindst fordi det kan bidrage til at flytte fokus fra et forsøg på præcist at definere, hvad følelser er, til en undersøgelse af, hvordan følelser gøres. Imidlertid kan tilgangen styrkes af et øget fokus på, hvad følelser gør i en given social sammenhæng. Som jeg vil vise i næste afsnit, er følelsespraksisser et særdeles operationalisérbart begreb, og det vinder ved at blive tænkt sammen med teorier, der betoner følelsers politiske betydning.

\section{Følelsespraksisser og politik: postkoloniale bidrag}

Siden den tidlige følelseshistorie har følelsers sammenblanding med politik været et centralt tema i historieskrivningen. Febvre opfattede således nazismen som et udtryk for, at farlige følelser var ved at overvælde intellektet med potentielt katastrofale følger.

Erkendelsen af forholdet mellem magt og følelser er også en af hovedårsagerne til den stigende interesse for dem inden for følelseshistorie i de senere år, om end der er forskellige opfattelser af, hvordan følelsernes politiske potentiale skal forstås. Eksempelvis fremhæver den tyske historiker Ute Frevert som motivation for at studere følelser historisk, at de kan påvirke udfaldet af sociale processer, tilskynde handlinger og afværge andre. ${ }^{62} \mathrm{Ud}$ fra et antropologisk perspektiv har Catherine Lutz og Lila Abu-Lughod argumenteret for følelsesdiskursers betydning i etableringen, forankringen og forandringen af konkrete magtrelationer. ${ }^{63} \mathrm{I}$ Tine Damsholts foucauldianske optik spiller følelserne ligeledes en central rolle i governmentale subjektiveringsprocesser.

I de senere år er det imidlertid særligt inden for queerstudier og postkoloniale studier, at der er blevet sat fokus på relationen mellem affekt/følelse og politik i bred forstand. Her vil jeg med udgangspunkt i forskellige postkoloniale studier (som jeg kender bedre end queerstudier) argumentere for, at selvom fokus har været på følelsernes politiske beskaffenhed snarere end på en diskussion af deres

62 Frevert, 2009:183. For en uddybning og eksemplificering af dette argument, se Frevert, 2011.

63 Abu-Lughod and Lutz, 1990:12-14. 
ontologiske status, kan postkoloniale analyser også ses som udsagn om følelsernes tilblivelse i et kontinuerligt kredsløb mellem den enkelte og samfundet.

Det er en basal præmis for den postkoloniale følelsesteori, at følelser ikke er sekundære fænomener i forhold til sociopolitiske forhold, men derimod er uadskillelige fra magt. Som kulturteoretikeren Sarah Ahmed har formuleret det: "[emotions] work to align some subjects with others against other others."64 Sagt på en anden måde: følelser gestalter det sociale landskab.

Den historiske antropolog Ann Laura Stolers teorier om kolonialismens affektive dimensioner har haft stor indflydelse på det postkoloniale felt. For Stoler udgør følelser et vigtigt aspekt af sociale kategoriseringer og dermed af de fundamentale skel mellem sort og hvid, eller europæer og ikke-europæer, som lå til grund for det koloniale styre. De koloniale stater, skriver Stoler:

"Attended minutely to the distribution of appropriate affect (what sentiments could be shown toward, and shared with, whom), to the relations in which carnal desires could be safely directed, to prescriptions for comportment that could distinguish colonizer from colonized - and, as important, to those that finely graded the distinctions of privilege and class among colonizers themselves." 65

Det koloniale styre afhang af promoveringen og reguleringen af specifikke mønstre af følelser og begær. Børn af hvide forældre, der voksede op i de oversøiske kolonier, skulle blandt andet lære kærlighed til det europæiske fædreland og foragt for de indfødtes levemåder og vaner for at kunne regnes som europæere. At gebærde sig på en følelsesmæssig passende måde var med andre ord en af nøglerne til at blive identificeret som europæer og dermed opnå eller bibeholde den status og de privilegier, som hvidhed indebar i den koloniale sociale orden. Følelsesstrukturer var derfor ifølge Stoler ikke et spejlbillede af de koloniale sociale hierarkier, men derimod konstituerende for disse hierarkier. ${ }^{66}$

I en Stoler-inspireret analyse undersøger kultur- og medieforskeren Amit Rai medlidenhedens eller medfølelsens politik i den koloniale verden. Selvom medfølelse eller medlidenhed (sympathy) ofte opfattes som en antihierarkisk følelse, fordi den forudsætter identifikation med den anden og bevægelse ved denne andens lidelse, argumenterer Rai for, at den koloniale medfølelse eller medlidenhed i realiteten var en forskelsteknologi. I den koloniale verden producerede følelsen kort sagt den ulighed, den i princippet skulle overvinde:

64 Ahmed, 2004a:42 Se også Ahmed, 2004b.

65 Stoler, 2001:832.

66 Stoler, 1992; Stoler har udviklet argumenterne i sine to efterfølgende monografier Stoler, 2002; Stoler, 2006. 


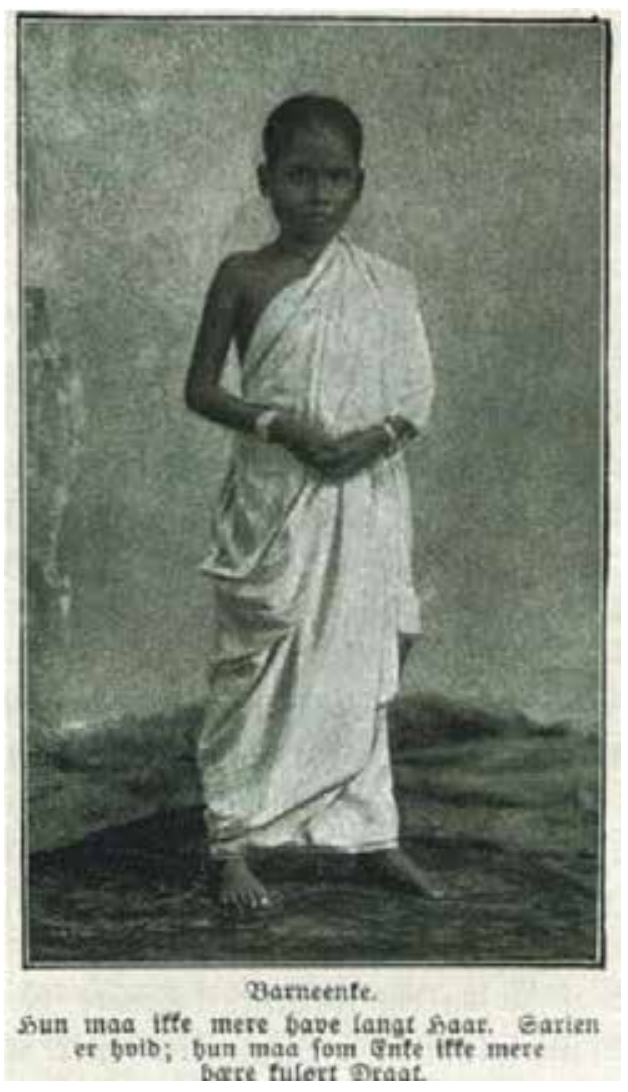

\author{
Illustration fra børnebogen Hindubørn af \\ Johanne Blauenfeldt (1905). Billedet viser \\ en indisk barneenke, et arketypisk objekt \\ for kolonial medlidenhed.
}

"The differences of racial, gender, and class inequalities that increasingly divided the object and agent of sympathy were precisely what must be bridged through identification. Yet without such differences, which were differences of power, sympathy itself would be impossible: In a specific sense, sympathy produces the very inequalities it decries and seeks to bridge." 67

Det var ikke kun inden for den koloniale stats rammer, at mobiliseringen og praktiseringen af forskellige følelser spillede en afgørende rolle i konstruktionen og vedligeholdelsen af den koloniale sociale orden. I min afhandling om danske missionærer i det koloniale Sydindien viste jeg, hvordan missionærerne medvirkede til at etablere særlige følelsesstrukturer, der underbyggede et kolonialt betinget socialt hierarki. ${ }^{68}$

Et eksempel er den følelsesopdragelse, som missionærerne i de første årtier af det 20. århundrede gjorde danske børn til genstand for. Gennem historier og illustrationer i missionspublikationer rettet mod børn, såvel som gennem kropslige praksisser som sangøvelser, forsøgte missionærerne at kultivere medlidenhed

67 Rai, 2002. For andre interessant analyser af "sympathy" som magtform, se Stevens, 2004; Rutherford, 2009.

68 Vallgårda, 2012. 
med indere hos de danske børn. Ifølge missionærernes fremstillinger manglede inderne ikke alene kendskab til Gud. Særligt de indiske børn og kvinder var også udsat for kontinuerlig mishandling i det hedenske samfund. Ved at lære de danske børn at forstå sig selv som materielt, socialt og åndeligt overlegne de indiske børn, og ved direkte at opfordre børnene til at ynke deres hedenske søstre og brødre, indlemmede missionærerne også de danske børn i et socialt hierarki, der rakte langt ud over de danske landegrænser. ${ }^{69}$

Hvis vi indtænker Monique Scheers begreb, kan missionærernes forsøg på at mobilisere og regulere børnenes følelser også ses som mere eller mindre bevidste følelsespraksisser. Disse praksisser udsprang af missionærernes egne forestillinger om, hvad der udgjorde et godt menneske - forestillinger, der var formet af de sociale strukturer, der gennem livsforløb havde indlejret sig i deres kroppe. Samtidig medvirkede praksisserne til at forme og udbrede specifikke koloniale sociale hierarkier. I en sådan forståelse af missionærernes følelsesopdragende tiltag, hænger erkendelse og følelse sammen. Endvidere ses disse praksisser som både konstituerede af og bidragende til konkrete magtrelationer.

I deres studie af britiske missionspublikationer fra perioden 1880-1920 undersøger sociolog Jane Haggis og historiker Margaret Allen ligeledes, hvordan missionærernes sprog og billedbrug var med til at etablere særlige affektive fællesskaber som understøttede koloniale sociale forskelle. Dette skete blandt andet gennem en fremstilling af de koloniserede som ude af stand til at opføre sig følelsesmæssigt passende. De koloniserede blev beskrevet som værende i deres følelsers vold - snarere end i stand til at styre deres følelser. "[They] were seen to express emotion in inappropriate or excessive ways, being happy, for example, when they should have been sad; laughing too hard or crying too much."70

Missionærerne stræbte efter at erstatte disse hedenske følelsesubalancer med et kristent, oplyst og civiliseret følelsesliv, men de religiøse følelsesreformer var tilsyneladende dømt til at mislykkes - de koloniserede konvertitter kunne aldrig rigtig finde ud af at føle rigtigt. Denne fiasko var imidlertid produktiv på et andet niveau: den understregede de fundamentale forskelle mellem de koloniserende og de koloniserede, som retfærdiggjorde den koloniale dominans. ${ }^{71}$ Også Haggis’ og Allens analyse kan tænkes sammen med følelsespraksisbegrebet, om end der her er mere fokus på skrivepraksisser end på kropslige handlinger.

Mens de fleste postkoloniale forskere har undersøgt, hvordan følelser og affekt skaber grænser og skel, peger andre på følelsernes potentielt set destabiliserende

69 Vallgårda, 2012.

70 Haggis and Allen, 2008:692-93. Det er bemærkelsesværdigt at manglende følelseskontrol - præcis som i Elias's store værk om disciplineringsprocessen diskuteret ovenfor - blandt missionærerne tilsyneladende kædes sammen med det det uciviliserede.

71 Haggis and Allen, 2008 Med hensyn til den produktive fiasko i missionsmødet, se også Vallgårda, 2011. 
rolle i forhold til de etablerede sociale hierarkier. I sin bog Affective Communities argumenterer litteraten Lela Gandhi således for, at affektive bånd var afgørende i antikolonial aktivisme i slutningen af det 19. århundrede i Indien og Storbritannien. Venskaber på tværs af de koloniale skillelinjer og den gensidige respekt og sympati, som disse venskaber indebar, var ifølge Gandhi med til at underminere de følelsesmæssige og sociale skel, der lå til grund for kolonialismen. ${ }^{72}$ Gandhi beskriver blandt andet, hvordan den britiske missionær C. F. Andrews i mødet med lederen af den indiske nationalistbevægelse, M. K. Gandhi i 1914 bøjede sig ned og kyssede hans fødder - et ritual, der i indiske sammenhæng forstås som tegn på respekt og ydmyghed, og som Andrews siden gentog med andre af Gandhis landsmænd. Med Leela Gandhis ord:

"The minor affective transactions of this closet drama import an incalculable excess into the impasse of colonial encounter, collapsing for a brief moment the mutually quarantined categories of colonizer and colonized."73

Dette kys, som Leela Gandhi benævner en "affektiv transaktion”, kan forstås som en følelsespraksis, der snarere end at forstærke den specifikke magtkonstellation, bidrager til dens underminering eller transformation.

Postkoloniale forskere har således vist, hvordan følelser både former og er formet af den givne sociale orden. Følelser kan både underbygge eller skærpe og ophæve eller svække sociale skel. Mange af de postkoloniale analyser kan med fordel tænkes sammen med Monique Scheers begreb, idet de fremstiller følelser som noget, der kan gøres på kulturelt og historisk specifikke måder, men som også gør noget ved den sociokulturelle kontekst inden for hvilken, de udøves.

\section{Konklusion}

Mens der inden for den nyere følelseshistorie har hersket relativt bred konsensus om, at følelser ikke skal forstås som intellektets modsætning, har der været større uenighed om følelsers - og affekts - status i relationen mellem individ og samfund, indre og ydre, partikulært og universelt såvel som mellem natur og kultur. Et omdrejningspunkt for debatterne har været, hvilke implikationer følelsernes status i sådanne relationer havde, dels for deres egen historicitet, dels for deres evne til at forårsage andre sociokulturelle og politiske forandringer. I socialkonstruktivistiske og poststrukturalistiske tilgange anskues følelser som socialt og diskursivt betingede og derfor stærkt varierende over tid og rum. De stærke re-

72 Gandhi, 2006. For analyser af kærlighedens ambivalente politik i koloniale kulturmøder, se McLisky, 2008 og Vallgårda, 2012:147-88.

73 Gandhi, 2006:15. 
aktioner på disse tilgange udtrykte imidlertid en utilfredshed med forestillingen om, at menneskets følelsesliv skulle reduceres til et produkt af sociale strukturer og kulturelle processer. Ifølge kritikerne indebar denne begrebsliggørelse en deterministisk opfattelse af den menneskelige tilværelse, som ikke rummede et (progressivt) forandringspotentiale. I nyere affektteori lokaliseres affekt netop i den autonome dynamik, der kan forklare kulturelle og følelsesmæssige forandringer over tid. Hidtil har affektteoretikerne imidlertid ikke klart teoretiseret forholdet mellem autonom affekt og de sociokulturelle strukturer.

Udfordringen synes derfor at være at finde frem til et følelsesbegreb, som dels tager højde for følelsernes sociale karakter, dels forklarer deres historiske foranderlighed og evne til at forårsage forandringer. Monique Scheers begrebsliggørelse af følelser som en form for praksis, der udspringer af en socialt struktureret krop, løser ikke endeligt problematikken. Derimod dirigerer følelsespraksisser den analytiske opmærksomhed hen på, hvordan følelser gøres. Selvom denne forflyttelse af fokus indebærer en risiko for, at spørgsmålet om følelsernes ontologiske status går fra at være et eksplicit diskussionspunkt til at være en implicit antagelse, muliggør studiet af praksisser andre former for erkendelse.

Følelsespraksisbegrebet bliver særligt frugtbart, når det forbindes med teorier om, hvordan følelser bidrager til reproduktionen eller omformningen af den sociale virkelighed, der har struktureret de kroppe, hvorfra praksisserne udspringer. Som diskussionen af eksempler fra den postkoloniale forskning viser, kan en sådan tilgang operationaliseres på produktive måder.

Efter min overbevisning er det netop det, at følelser er uadskillelige fra magt, der gør dem interessante og vigtige at undersøge i et historisk perspektiv. Ved hjælp af begrebet følelsespraksisser i kombination med fokus på følelsernes sociopolitiske implikationer kan vi begynde at forstå den kontinuerlige vekselvirkning mellem individets subjektive følelseserfaringer og de skiftende sociokulturelle rammer, inden for hvilke de udfolder sig. Vi kan, med andre ord, undersøge, hvordan følelser i forskellige historiske og kulturelle kontekster både gør og gøres.

\section{Litteraturliste}

Abu-Lughod, Lila and Catherine A Lutz (1990), 'Introduction: emotion, discourse, and the politics of everyday life', in Abu-Lughod, Lila and Catherine A Lutz (eds.), Language and the politics of emotion (New York: Cambridge University Press).

Ahmed, Sara (2004a), The Cultural Politics of Emotion, (New York: Routlege). - do - (2004b), 'Collective Feelings: Or, the Impressions Left by Others', Theory, Culture \& Society, 21 (2), 25-42. 
Bourke, Joanna (2003), 'Fear and Anxiety: Writing about Emotion in Modern History', History Workshop Journal, 55 111-33.

Clough, Patricia T and Jean Halley (2007), The affective turn: Theorizing the social, (Duke Univ Press).

Damsholt, Tine (2004), 'Følelser og subjektivering. Et fædrelandskærligt eksempel', Tidsskrift for Kulturforskning, 3 (2), 5-28.

- do - (2008), 'Making Citizens: On the Genealogy og Citizenship Ceremonies', in Mouritsen, P. and K. E. Jørgensen (eds.), Constituting Communities. Political Solutions to Cultural Conflict (Basingstoke and New York: Palgrave Macmillan), 53-73.

Dixon, Thomas (2003), From Passions to Emotions. The Creation of a Secular Psychological Category, (Cambridge: Cambridge University Press).

- do - (2011), 'Sensibility and history: The importance of Lucien Febvre', The History of Emotions Blog.

Durkheim, Emile (1982), Rules of Sociological Method, (The Macmillan).

- do - (2001), The Elementary Forms of Religious Life, (Oxford: Oxford University Press).

Elias, Norbert (2000), The Civilizing Process. Sociogenetic and Psychogenetic Investigations, (Malden: Blackwell Publishing).

Febvre, Lucien (1941), 'La sensibilité et l'histoire: Comment reconstituer la vie affective d'autrefois?', Annales d'histoire sociale, 3 (1/2), 5-20.

Foucault, Michel (1971), 'Nietzsche, la généalogie, l’histoire', in Bachelard, Suzanne (ed.), Hommage à Jean Hyppolite (Paris: Presses universitaires de France), 145-72.

Frederiksen, Maja Bissenbakker (2012), 'Styr dine følelser! En affektiv vending', Varia, 9 4-18.

Frevert, Ute (2011), Emotions in History - Lost and Found, (Budapest, New York: Central European University Press).

Frevert, Ute von (2009), 'Was haben Gefühle in der Geschicte zu suchen?', Geschicte und Gesellschaft, 35 (2), 183-208.

Gandhi, Leela (2006), Affective Communities. Anticolonial Thought, Fin-deSiècle Radicalism, and the Politics of Friendship, (Duke University Press).

Gay, Peter (1986), Freud for Historians, (New York, Oxford: Oxford University Press).

Hacking, Ian (1995), 'The looping effect of human kinds', in Sperber, Dan, David Premack, and Ann James Premack (eds.), Causal Cognition. A Multidisciplinary Debate (Oxford: Clarendon Press), 351-94.

Haggis, Jane and Margaret Allen (2008), 'Imperial Emotions: Affective Communities of Mission in British Protestant Women's Missionary Publications c. 1880-1920', Journal of Social History, 41 (3), 691-716.

Hemmings, Claire (2005), 'Invoking Affect', Cultural Studies, 19 (5), 548-67. 
Hitzer, Bettina (2011), 'Emotionsgeschichte - ein Anfang mit Folgen', Hsozkult, Hochschild, Arlie Russell (2012), The Managed Heart. Commercialization of Human Feeling, (Berkeley: University of California Press).

Jespersen, Astrid Pernille (2008), 'Engagement i arbejdet? Konsultationsprocesser hos danske praktiserende', (University of Copenhagen).

Lutz, Catherine and Geoffrey M. White (1986), 'The Anthropology of Emotions', Annual Review of Anthropology, 15 405-36.

Massumi, Brian (2002), Parables for the Virtual: Movement, Affect, Sensation (Post-Contemporary Interventions), (Duke University Press Books).

McLisky, Claire (2008), 'Professions of Christian Love: Letters of Courtship Between Missionaries-To-Be Daniel Matthews and Janet Johnston', in Barry, Amanda, et al. (eds.), Evangelists of Empire? Missionaries in Colonial History (Melbourne: University of Melbourne eScholarship Research Centre (online)), Medick, Hans and David Sabean (1984a), 'Interest and emotion in family and kinship studies: a critique of social history and anthropology', in Medick, Hans and David Sabean (eds.), Interest and emotion: essays on the study of family and kinship (Cambridge: Cambridge University Press),

- do - (1984b), 'Introduction', in Medick, Hans and David Sabean (eds.), Interest and emotion: essays on the study of family and kinship (Cambridge: Cambridge University Press),

Nordland, Hugo (2012), 'Eviga emotioner och konstruerade känslor. Riktningar inom känslornas historia’, Scandia, 119-26.

Pernau, Margrit (2012), 'Male Anger and Female Malice: Emotions in Indo-Muslim Advice Literature', History Compass, 10 (2), 119-28.

Plamper, Jan (2010), 'The History of Emotions: An Interview with William Reddy, Barbara Rosenwein, and Peter Stearns', History and Theory, 49 (2), 237-65.

- do - (2012), Geschichte und Gefühl: Grundlagen der Emotionsgeschichte, (Munich: Siedler).

Rai, Amit (2002), The Rule of Sympathy. Sentiment, Race, and Power, 17501850, (New York: Palgrave).

Reddy, William (2001), The Navigation of Feeling, (Cambridge: Cambridge University Press).

- do - (1997), 'Against Constructionism', Cultural Anthropology, 38 (3), 327-41. Rosaldo, Michelle Z. (1983), 'The Shame of Headhunters and the Autonomy of Self', Ethos, 11 (3), 135-51.

- do - (1984), 'Toward an anthropology of self and feeling', in Shweder, Richard A. and Robert Alan LeVine (eds.), Culture theory: essays on mind, self and emotion (Cambridge: Cambridge University Press), 137-58. 
Rosenwein, Barbara (2010), 'Problems and Methods in the History of Emotions', Passions in Context: International Journal for the History and Theory of Emotions, 1

- do - (2002), 'Worrying about emotions in history', The American Historical Review, 107 (3), 821-45.

Rutherford, Danilyn (2009), 'Sympathy, State Building, and the Experience of Empire', Cultural Anthropology, 24 (1), 1-32.

Scheer, Monique (2012), 'Are Emotions a Kind of Practice (and is That What Makes Them Have a History)? A Bourdieuan Approach to Understanding Emotion', History and Theory, 51 193-220.

Schjerning, Camilla (2013), 'Følelsernes fællesskaber: Moralske følelser og sociale relationer i København, 1771-1800’, (University of Copenhagen).

Shouse, Eric (2005), 'Feeling, Emotion, Affect', M/C Journal, 8 (6),

Solomon, Robert (1988), 'On Emotions and Judgments', American Philosophical Quarterly, 25 (2), 183-91.

Stearns, Peter N. (2008), 'History of Emotions. Issues of Change and Impact', Handbook of Emotions (17-31).

Stearns, Peter N. and Timothy Haggerty (1991), 'The Role of Fear: Transitions in American Emotional Standards for Children, 1850-1950', American Historical Review, 96 63-94.

Stearns, Peter N. and Carol Z. Stearns (1985), 'Emotionology: Clarifying the History of Emotions and Emotional Standards', The American Historical Review, 90 (4), 813-36.

Stevens, Laura (2004), The Poor Indians. British Missionaries, Native Americans, and Colonial Sensibility, (Philadelphia: University of Pennsylvania Press).

Stoler, Ann Laura (2002), Carnal Knowledge and Imperial Power. Race and the Intimate in Colonial Rule, (Berkeley: University of California Press).

- do - (2006), 'Intimidations of Empire: Predicaments of the Tactile and Unseen', in Stoler, Ann Laura (ed.), Haunted by Empire. Geographies of Intimacy in North American History (Durham: Duke University Press), 1-22.

- do - (2001), 'Tense and Tender Ties: The Politics of Comparison in North American History and (Post) Colonial Studies', The Journal of American History, 88 (3), 829-65.

- do - (1992), 'Sexual Affronts and Racial Frontiers: European Identities and the Cultural Politics of Exclusion in Colonial Southeast Asia', Comparative Studies in Society and History, 34 (3), 514-51.

Vallgårda, Karen (2011), 'Adam's Escape. Children and the Discordant Nature of Colonial Conversions', Childhood, 18 (3), 298-315.

- do - (2012), 'Bringing Children Into the Fold. Danish Missionaries and Tamils in Colonial South India, 1864-1918', (University of Copenhagen). 
Wessel, Peter (2012), 'Grief, sickness and emotions in the narratives of the shamefaced poor in late eighteenth-century Copenhagen', in Gestrich, Andreas, Elizabeth Hurren, and Steven King (eds.), Poverty and Sickness in Modern Europe: Narratives of the Sick Poor, 1780-1938 (London: Continuum), 35-50.

\section{English Summary}

The history of emotions is currently a rapidly expanding field. Probing a number of important recent contributions to the field, this article discusses the central theoretical and methodological challenges that researchers must confront when interrogating emotions in different historical contexts: How should we define emotions? To what extent are they socially constituted and culturally contingent? Is there anything universal about human emotional experience? The article makes the case that the greatest challenge for historians of emotion is to conceptualize emotions in a way that captures their social constitution while at the same time implies a principle of emotional changes over time. Taking Monique Scheer's concept of "emotional practices" as a starting point, the article argues that it could productively be combined with theories that point to the sociopolitical effects of emotions. This conceptualization makes it possible to shift the theoretical focus away from the emotions' ontological status towards an analysis of how emotions are done and with what effects. Examining different empirical examples from postcolonial studies, the article finally shows how the concept of emotional practices is useful to think with in analyses of the sociopolitical implications of emotions. 